\title{
Developing Teacher-Trainees' Assessment Awareness in the EFL Classroom through Project-Based Learning Activity
}

\author{
Elena Galichkina \\ Astrakhan State University
}

\begin{abstract}
Correspondence concerning this article should be addressed to Elena Galichkina, Astrakhan State University, 20a Tatishcheva str., Astrakhan, Russian Federation, 414056. E-mail: elenagalich@rambler.ru
\end{abstract}

\begin{abstract}
Due to the Russian State Educational Standard, beginning ESL teachers should possess professional competences, including being ready to implement in their classrooms modern methods and techniques of assessing students' achievement. However, teacher trainees are not provided with opportunities to acquire assessment skills during their learning process. Developing teacher trainees' professional competencies during a practicum, that is, a fourweek period of school-based practice teaching, may be a way to solve this problem. The key aim of the study is to investigate whether experiencing project-based learning (PBL) activity during a content-based course might raise teacher trainees' assessment awareness and enable them to put assessment skills to practical use in their future classrooms. The methodology of the present study includes developing assessment criteria for self- and peer-reflective weekly journals, developing survey questions and descriptive rubrics for grading oral presentations of PBL activity. The results of the research demonstrate that experiencing a PBL activity as a learner can trigger a deeper assessment awareness of project-based learning activities and can help develop confidence in recognizing teacher trainees' personal strong points essential for their future professional life. By experiencing a PBL activity, teacher-trainees gain insights about its process and observe how students' self-awareness and confidence in assessment practice are fostered through authentic tasks during a content-based course. This study therefore proposes that project-based learning activity can raise teacher-trainees' assessment awareness and should be integrated in the teacher-training ESL course at the Astrakhan State University, Russia.
\end{abstract}

Keywords: project-based learning, Russian students, teacher trainees' assessment, assessment awareness, project-based learning (PBL) assessment

Higher education has evolved in recent years toward a shift from the instruction-based paradigm focusing on the central role of the teacher to a learnercentered paradigm focusing on the role of the student. This paradigmatic shift puts an emphasis on providing students with a set of professional competences upon which they can build throughout their future careers. According to the new Russian State Educational Standards, teacher-trainees should have the following professional competences: be ready to implement modern methods and techniques of assessing students' achievement in order to provide for effective learning and development (FSES, 2011).

Modern Russian universities, among them
Astrakhan State University, should implement educational standards by prioritizing the development of practical skills, that is, competences. Though the European Commission states that new teachers should receive systematic training at the beginning of their professional activities (European commission, 2010), we think that such training should start while teachertrainees are still at the university.

In Astrakhan State University, students have an opportunity to start developing professional competences during their practicum, that is, a fourweek period of school-based practice teaching supervised by experienced teachers. Unfortunately, they are not well-equipped for this kind of work and, 
according to teaching-supervisors, they especially need training in assessing all kinds of project activities.

\section{Materials and Methods}

\section{Theory}

A close review of the literature reveals four themes related to difficulties in assessing PBL: selecting an assessment mode; deciding what to assess; creating assessment rubrics; deciding whether to involve students in assessment. First, project-based learning does not lend itself to traditional modes of assessment such as tests or quizzes. As a result, students in projectbased learning have been assessed in a variety of ways: from traditional paper-and-pencil tests to new modes of assessment such as case-based assessment, selfand peer assessment, performance-based assessment and portfolio assessment (Project-based learning handbook, 2006).

Second, assessment of PBL processes and products presents a unique problem for ELT practitioners and researchers. Some of them advocate the primacy of process over product (Stater et al., 2006; Hunaiti et al., 2010), while others believe that assessment of the projects should cover both product and process (Bryer, 2006; Debski, 2006). This action research assumes the importance of both process and product in PBL assessment.

Third, many educational manuals and articles on assessment in PBL are more focused on the theoretical background for assessment in PBL and offer clues on how to design PBL lessons (Bell, 2010; Debski, 2006) rather than explaining the practical part, particularly, how a teacher assesses students.

Fourth, there is some debate about whether teachers should involve students in actual assessment processes. In spite of some skepticism about the validity of students' self- and peer assessments (Nightingale et al., 1996), few researchers urge teachers to involve students in the process of self- and peer assessment, stating that, "students are able to iteratively assess each other through self-reflection and peer-review" (Harrington, 1995, p. 8).

It should be noted that few studies to date have examined the extent to which teachers are actively engaged in efforts to improve students' assessment skills and awareness despite educators' widespread appreciation of the importance of assessment skills and their belief that future teachers should be provided with more opportunities to acquire assessment skills. Stiggins, for example, claims that there continues to be relatively little emphasis on assessment in training teachers (Stiggins, 2004, p. 20). In fact, there is very little empirical evidence to date to indicate the extent to which teachers are actively engaged in efforts to improve students' assessment skills and awareness in pre-service teacher training.

\section{Research}

The purpose of this study is to develop teacher trainees' assessment awareness and competences through experiencing project-based learning activity that might enable them to put their assessment skills to practical use in their future classrooms. Our aim was to develop students' assessment awareness in the EFL classroom through project-based learning activity. To achieve this, we began by posing the following research questions:

1. What problems might trainee-teachers face while assessing project based learning activities during their practicum?

2. How can we help trainee-teachers implement and assess PBL activities in their own classrooms?

3. How will trainee-EFL-teachers feel about planning and assessing PBL activities after experiencing a PBL activity as a learner?

\section{Participants}

The participants were 11 third-year students of Astrakhan State University, Russia, Department of English Philology: nine females and two males, average age of 18.5 years. The students' training direction is 050100 Pedagogical Education (qualification / degree "Bachelor"). All the participants were informed about the purpose of the research, and all were involved in the research of their own free will.

\section{Methods}

The study draws on the following theoretical frames: Hadim and Esche's (2002) notions of a PBL as a teaching approach that emphasizes student participation in the learning process to construct their own knowledge in an active learning environment; Wallace's (1991) alternative model for teacher education claiming that it is possible to develop experiential knowledge through the observation of practice. Additionally, assessment for learning theory (Brown, 2004; Pooler, 2012), which emphasizes the importance of developing students' awareness of assessment methods for making further progress, rather than merely providing them with a score, provided inspiration at the start of my action research.

This study followed an action research approach (Burns, 2010). The methods of data collection in this study consisted of a blend of qualitative techniques chosen to help us capture how teacher-trainees made sense of their PBL experiences (Burns, 2010) and 
quantitative analysis through the interpretation of the results of the PBL activity which students participated in.

The data were collected through several sources:

(1) written questionnaire responses to openended questions for beginning teachers of English and senior EFL students who have had a teaching practicum;

(2) observational notes taken during a discussion session on how trainee-teachers can be helped to implement and assess PBL activities in their own classrooms;

(3) teacher-trainees' self- and peer reflective weekly journal notes on their own experience of PBL activity;

(4) teacher-trainees' written reflections and comments to open-ended questions posed at the end of the PBL activity;

(5) teacher-trainees' attitudinal survey results including both open items and semi-structured items with a four point Likert scale.

The qualitative data were collected in their naturally occurring contexts. In order to develop students' assessment awareness, teacher-trainees participating in this study were encouraged to experience a PBL activity in order to observe, model and further apply knowledge gained to their future classroom teaching.

This action research comprised five stages:

1. Stage 1. Trainee-teachers are questioned about difficulties they face while assessing project-based learning activities during their practicum (see Appendix 1)

2. Stage 2. Discussion session with trainee-teachers on how to help them implement and assess PBL activities in their own classrooms.

3. Stage 3. Teacher-trainees are involved in a projectbased learning activity, during which they: keep self- and peer reflective weekly journals on their experience of the process of PBL activity; self- and peer-assess the oral presentation of the project's results; peer-assess the project's product (a printed booklet); write reflection comments to open-ended questions posed at the end of the PBL activity.

4. Stage 4. The instructor makes a presentation on "Assessment in PBL", during which teacher-trainees are given an opportunity to practice authentic tasks (3 scenarios).

5. Stage 5. Teacher-trainees write a survey on what they feel about planning and assessing PBL activities after experiencing a PBL activity as a learner.

The questionnaire in Stage $\mathbf{1}$ was used to discover what challenges third-year trainee- teachers might face while assessing project-based learning activities during their future practicum on the fourth course. The questionnaire included three open-ended questions:
- Did you implement a PBL activity during the practicum?

- What challenges did you face as you implemented a PBL activity?

- What problematic issues related to PBL assessment can you single out?

The total number of respondents was 35 students from Astrakhan State University who have recently experienced the practicum and 35 beginning teachers of English from secondary schools in Astrakhan.

Stage 2 of the action research was focused on helping and preparing teacher-trainees to assess PBL activities in their future classrooms. The 30-minute discussion session was held to discover what kind of help can be provided for trainee-teachers to implement and assess PBL activities since the role of the teacher, according to the socio-constructivists, is as a helping hand. An unstructured class observation method was employed to observe the class with a detailed record of observational notes that included reflective and analytical observations.

In stage 3, we wanted to give teacher-trainees content awareness from previously learnt units and an opportunity for them to participate in PBL in terms of self-actualization and to provide an educational experience that will train them for future practicum. During the project, students were to craft an informative booklet "An Overview of Cinemas and Theatres in Astrakhan" for visitors and guests of the town. The booklet should include the following items: information on recreational centers in Astrakhan, description of their advantages and disadvantages, their location, website addresses, time schedule, etc. It should also include visitors' opinions on the cinemas and theatres' repertoire, services, etc.

Assessment of the project work comprised two parts: process assessment and product assessment.

1. Process assessment was conducted based on Goldfinch's (1994) and Lejk and Wyvill's (2001) Self and Peer Reflective Journals. We adapted them by accompanying the suggested criteria with detailed questions (see Appendix A). Assessment of the group work was focused on seven criteria: Group Participation; Responsibility and Time Management; Contribution; Creativity/Originality; Communication Skills; General Team Skills; Technical Skills. Keeping reflective journals and asking students to self- and peer assess was a formative way to get students to reflect on their own and their group mates' performance in the project. Here are some of the students' comments from their Self- Reflective Journals:

- "I should be more active and suggest new ideas".

- "Next week I want to make a schedule for myself for every day to work on the project".

Here are some of the students' comments from their Peer-Reflective Journals: 
- "I think this person is the most active and initiative in our group. She has made a great share of work, namely diagramming and creating the general view of the booklet. And she is also responsible as she has kept the time limits of each task".

- "I think that Irina should be more active".

2. Product assessment focused on the Groups' Oral Presentation, Printed Booklet and Written Report.

\section{Groups' Oral Presentation}

The effectiveness of the presentation as a whole, in terms of its content (focus on task fulfillment), clarity and coherence of ideas, introduction and conclusion, visual aids and creativity/originality was assessed during the Groups' Oral Presentation. To become knowledgeable practitioners, teacher-trainees were involved in peer assessment (members of group 1 assessed members of group 2, and visa versa). The students were asked two open-ended questions: "What did you like most about Group $1 / 2$ presentation?" and "What can be improved next time the group presents the project results?" In their comments they wrote:

- The whole group has made a great job. I liked friendly atmosphere in the group.

- Iliked the way the members of the group answered. They were confident. It was clear that they really worked hard.

- Next time they should give more details, especially how they conducted the survey.

Every student gave a 5-minute presentation during the 30-minute group presentation (6 persons) and was assessed individually. The assessment criteria considered the student's individual ability to focus on task fulfillment (content), fluency and coherence of speech, awareness of audience (interaction with the audience, ability to engage and address the audience, eye-contact), language (variety of vocabulary, grammar range and accuracy, pronunciation), response to questions, and whether he/she managed to keep to the time limit (5 min.). The results of the Oral Presentation Peer Assessment fairly coincide with the teacher's assessment.

\section{Printed Booklet}

There were five assessment criteria for the booklet: content; organization, language, audience appeal and originality / creativity. Overall, the students appreciated their participation in this kind of activity. They liked the design of the peer group's booklet. They also concluded that they should pay more attention to the layout, grammar, choice of words and be aware of the target audience.

\section{Written Report}

In the Written Reports, teacher-trainees presented their reflections on the project. This encompassed their ideas on whether they liked participating in the project, as well as their evaluation of the strengths and weaknesses of the project and of themselves in carrying it out. In their comments to 10 openended questions students remarked that it was a new experience for them, that it helped them to understand how to work in a team, how to manage time properly and to interview people. Surprisingly, only one student admitted having difficulties while working in a team as he was used to doing everything alone. The majority of the students wrote that they learnt a lot of new things: improved communication skills, learnt to make diagrams, questionnaire and conduct a survey. Students also admitted that doing a group project is a good way to "learn more about your group mates".

In Stage 4, to cultivate teacher-trainees' assessment awareness, a presentation was conducted on "Assessment in PBL", during which students learnt about different approaches to PBL assessment, purposes, methods and instruments for assessing projects. Teacher- trainees were also trained to create descriptive rubrics for grading oral presentations.

Finally, based on what students have learnt during the presentation on "Assessment in PBL" and their own experience of the PBL activity, they practiced authentic tasks. For this reason, three project scenarios were chosen from New Matrix, the book used in Basic Education curriculum in some schools in Astrakhan, Russia, for the $9^{\text {th }}, 10^{\text {th }}$ and $11^{\text {th }}$ grades.

Here is an example of the first scenario chosen from New Matrix for the $9^{\text {th }}$ grade.

\section{Scenario 1.}

Follow these guidelines to help you complete your project.

Project title: Historical Places in Russia travel brochure.

1. Work in groups. Talk about places that are historically important to Russia, for example, Izborsk and Pskov - the longest held fortresses on Russia's Western frontier (5-15th century).

2. Choose four places and decide who is going to research each one. Each person will collect photos or drawings, and make notes, for example: about the location, the historical events it is linked to, what it is like today.

3. Create a brochure that is attractive and clear. Write a short paragraph about each place. Find some good pictures to illustrate the brochure.

4. Present your brochure to the class.

During the final $5^{\text {th }}$ Stage to examine whether experiencing a PBL activity as a learner helped teacher-trainees to plan assessment for PBL 
activities, 11 students were asked to complete the survey consisting of one open-ended item and three questions based on a four-point Likert scale (strongly agree, agree, disagree, strongly disagree). Students chose an answer that best corresponded with their views. Also a free-text "Please provide a few explanatory details or examples here" option was added to get "how/why" data.

The first open-ended question was: "In what way has experiencing a PBL activity as a learner helped you to plan assessment for PBL activities?" Inductive coding was used (Burns, 2010) to analyze and synthesize the data obtained. The data was scanned carefully to see what categories 'emerged' from the data and the following categories were singled out

Table 1

Students' feelings about PBL activity experience

\begin{tabular}{|c|c|}
\hline Categories & Reactions \\
\hline $\begin{array}{l}\text { Students' feelings } \\
\text { about PBL activity } \\
\text { experience } \\
\text { confidence }\end{array}$ & $\begin{array}{l}\text { Now I clearly understand what I } \\
\text { should do as a teacher, how I can help } \\
\text { and assess my pupils. } \\
\text { Now I know that there are several } \\
\text { stages in project work. } \\
\text { Now I know the process from the } \\
\text { 'inside'. } \\
\text { Now I know that a project has a goal, } \\
\text { aims, its own structure and stages. }\end{array}$ \\
\hline $\begin{array}{l}\text { Students enhanced } \\
\text { various skills } \\
\text { - } \quad \text { collaboration } \\
\text { skills } \\
\text { - } \quad \text { time-manage- } \\
\text { ment skills } \\
\text { - } \text { self-awareness } \\
\text { skills }\end{array}$ & $\begin{array}{l}\text { I learnt to make a brochure } \\
\text { I learnt to conduct a questionnaire } \\
\text { I learnt to work in a team. } \\
\text { I learnt to organize work myself. } \\
\text { I understood my own strong and weak } \\
\text { points. } \\
\text { I understood how difficult it is for me } \\
\text { to work in a team. }\end{array}$ \\
\hline $\begin{array}{l}\text { Students understood } \\
\text { the need for teacher's } \\
\text { strong guidance }\end{array}$ & $\begin{array}{l}\text { I strongly realized how important the } \\
\text { role of the teacher is: she/ he should } \\
\text { guide the students all the way through } \\
\text { the project. }\end{array}$ \\
\hline $\begin{array}{l}\text { Students' motivation } \\
\text { was raised. }\end{array}$ & $\begin{array}{l}\text { It aroused my interest in learning } \\
\text { English. }\end{array}$ \\
\hline
\end{tabular}

\section{Results and Discussion}

According to the Stage 1 questionnaire results, the majority of respondents (20 students, or $57 \%$ and 30 teachers, or $60 \%$ ) stated that they implemented a PBL activity in their classrooms. A very high percentage of trainee-teachers (96\%) noted that they are positive about incorporating project-based learning activities into their classroom practice. Some of them even say that learners really enjoy such activities and always ask to involve them in projects. Many trainee-teachers believe that the most difficult aspect of PBT is assessment (68\%), and developing meaningful rubrics can be a challenge (56\%). The most frequent response to the question "What challenges did you face as you implemented PBL activity?" was lack of experience in PBL assessment, criteria for assessment, and need for training in assessment.

Here are some of the answers:

- I often involve my pupils in project work. Each unit of our textbook finishes with "A Project File" but the teacher's book provides no guidance on how to carry out the assessment. My pupils enjoy such kind of activities, especially they are enthusiastic about creating brochures, posters, conducting surveys and making questionnaires. For me, the most difficult aspect of PBT is assessment procedure. There are no standardized criteria and detailed descriptors that might help a teacher and serve as guidance for planning and delivering high quality assessment.

Somewhat unexpectedly, only one of the trainee teachers claimed to have experienced no challenges while implementing PBL activity.

Answering the question, "What problematic issues related to PBL assessment can you single out?" the majority of the questionnaire respondents pointed out the issue of assessment criteria in PBT and the scope of assessment (should it aim at assessing the product only or should it reflect on the process of project work).

Results of the discussion session conducted during Stage 2 are shown below in Table 2.

The results show that students' involvement in the assessment process is low (65\%), as they never got to self- or peer-assess. Also, many students admitted that they do not know what kind of help they want from their teacher, which might be suggestive of their low self-awareness.

According to the Stage 3 Process assessment results, the majority of self and peer assessment grades are the same (equal/matching) or very close ( 6 out of 11). Thought some of the students (4 out of 11) underestimated themselves, giving lower grades. Surprisingly, only one student overestimated himself (4 Good vs. 3 Fair). Generally, students admitted in their reflective journals that they felt relatively positive toward self- and peer assessment because it helped them to structure the learning process of the group. But they also mentioned they had mixed feelings about their capability to assess each other in a fair way. The results are consistent with earlier studies conducted by Segers and Dochy (2001).

During Stage 4, teacher-trainees were trained to create descriptive rubrics for grading oral presentations because much of project work revolves around presenting ideas and results to peers. A descriptive 
rubric for grading oral presentations is presented in Appendix B. It includes the following criteria: content, fluency and coherence of speech, awareness of audience, language, response to questions, stayed in time limit and requirements for excellent, good and fair grades in this project. At the end of Stage 4, learners were able to properly identify objectives, evaluation criteria and develop project assessment plans for three scenarios.

According to the Stage 5 results, the majority of students reported developing significant confidence through experiencing a PBL activity as a learner, both in recognizing their personal strong and weak points as well as in reinforcing various skills.

Three survey questions based on a four-point Likert scale (strongly agree, agree, disagree, strongly disagree) also aimed at gathering information about my students' attitudes to the effects of the intervention process. The data is presented in numerical form, assigning 1 for strongly disagree, 2 for disagree, 3 for agree and 4 for strongly agree. The responses to the three questions based on the four-point Likert scale are given below in Table 3 .

The total number of respondents was 11 . The results show that students gave the highest average rating (3.8) for practicing scenarios (working out assessment plans, creating descriptive rubrics) as they think that it helped them to implement and assess PBL. The lower grade (3.3) was given to their own experience of a PBL activity. They also appreciated the teacher's training on Assessment in PBL (3.1).

\section{Conclusion}

At the start of the study, a number of challenges associated with enacting project-based learning were mentioned. These issues were identified in Stage 1 of this project by questioning teachers who often involve their pupils in project work. Questionnaire results suggested a number of reasons why teachers face challenges assessing PBL activities in their classrooms, mainly attributable to lack of experience in PBL assessment themselves. Based on these findings, we recommend that graduates and future teachers should be prepared to assess PBL. To be effective in their roles, teacher-trainees should continually expand their knowledge and skills to implement the best educational practices. Thus, there is a growing need for university programs to provide the extensive range of learning experiences necessary for graduates to become effective educators. Once students graduate, meet their state's certification requirements, and

Table 2

Discussion session results

\begin{tabular}{|c|c|c|c|c|c|c|}
\hline Sequence of actions & \multicolumn{2}{|l|}{ Students' ideas } & \multicolumn{4}{|c|}{ Analysis } \\
\hline $\begin{array}{l}\text { 1. The teacher asks students what } \\
\text { assessment is and whether they were } \\
\text { involved in assessing a PBL activity } \\
\text { during the previous years of their } \\
\text { learning. }\end{array}$ & $\begin{array}{l}\text { Students want to know more abc } \\
\text { assessment, particularly abc } \\
\text { approaches to assessing a PBL activi } \\
\text { Students say that they have never be } \\
\text { involved in self- and peer assessment }\end{array}$ & & \multicolumn{4}{|c|}{$\begin{array}{l}\text { Students had never participated in } \\
\text { self- and peer assessment. Students are } \\
\text { interested in PBL assessment. }\end{array}$} \\
\hline $\begin{array}{l}\text { 2. Students and teacher brainstorm } \\
\text { implementation and assessment of PBL } \\
\text { activities in the classroom. The teacher } \\
\text { asks students about how she can help } \\
\text { her trainee teachers to implement and } \\
\text { assess PBL activity they are involved in. }\end{array}$ & $\begin{array}{l}\text { Students brainstorm in groups. } \mathrm{T} \\
\text { majority do not know what kind } \\
\text { help they need, but some of th } \\
\text { suggested the teacher should carry ou } \\
\text { presentation on assessment in PBT. }\end{array}$ & & \multicolumn{4}{|c|}{$\begin{array}{l}\text { Students would like to attend teacher's } \\
\text { presentation on “PBL assessment”. }\end{array}$} \\
\hline \multicolumn{7}{|l|}{$\begin{array}{l}\text { Table } 3 \\
\text { Survey results }\end{array}$} \\
\hline & & $\begin{array}{l}\text { Strongly } \\
\text { agree }\end{array}$ & Agree & Disagree & $\begin{array}{l}\text { Strongly } \\
\text { disagree }\end{array}$ & $\begin{array}{l}\text { Average } \\
\text { rating }\end{array}$ \\
\hline & & 4 & 3 & 2 & 1 & \\
\hline \multicolumn{2}{|c|}{$\begin{array}{l}\text { Question } 2 . \text { How strongly do you agree with the following statement: "Experiencing } \\
\text { a PBL activity as a learner prepared me to implement and assess PBL activities in my } \\
\text { own classroom." }\end{array}$} & $4 \%$ & $7 \%$ & $0 \%$ & $0 \%$ & 3.3 \\
\hline \multicolumn{2}{|c|}{$\begin{array}{l}\text { Question 3. How strongly do you agree with the following statement: “Teacher's } \\
\text { training on Assessment in PBT prepared me to implement and assess PBL activities } \\
\text { in my own classroom.” }\end{array}$} & $2 \%$ & $9 \%$ & $0 \%$ & $0 \%$ & 3.1 \\
\hline \multicolumn{2}{|c|}{$\begin{array}{l}\text { Question 4. How strongly do you agree with the following statement: "Practicing } \\
\text { Scenarios (working out assessment plans, creating descriptive rubrics) prepared me } \\
\text { to implement and assess PBL activities in my own classroom." }\end{array}$} & $9 \%$ & $2 \%$ & $0 \%$ & $0 \%$ & 3.8 \\
\hline
\end{tabular}


are employed, they start to learn through their own experience. But we believe this "experiential stage" can start earlier, namely during their university studies.

At first glance, all the project stages (stage 3, 4, 5) described above may seem too time consuming. However, one must consider their advantages. Experiencing a PBL activity as a learner helped participants to gain insights about its process, and practicing authentic tasks fostered students' self awareness and confidence in assessment awareness. In interpreting these findings we must remember that the research was focused only on eleven learners and the studies with larger groups of learners are needed to further explore the wider effectiveness of experiential learning for developing assessment awareness in PBL. In judging the effectiveness of developing confidence through experiencing a PBL activity as a learner we also relied solely on our teacher-trainees' responses.

Teacher-trainees' assessment awareness can be developed if teachers spend more time in the classroom focusing on a combination of experience-observation and experience-in-action. This study has enabled us to enhance our own knowledge of approaches to PBL assessment and we hope it will encourage other teachers to improve the assessment skills of their learners too.

\section{References}

Brown, S. (2004). Assessment for learning. Learning and Teaching in Higher Education, 1(X), 81-89.

Burns, A. (2010). Doing action research in English language teaching. New York, NY: Taylor \& Francis.

European commission staff working document SEC. (2010). Retrieved from http://ec.europa.eu/ education/library/publications/handbook0410_ en.pdf

Federal state educational standard FSES. (2011). Retrieved from http://narfu.ru/upload/iblock/f26/ fgos_050100.pdf

Goldfinch, J. (1994). Further developments in peer assessment of group projects. Assessment \& Evaluation in Higher Education, 19, 29-35.

Hadim, H. A., \& Esche, S. K. (2002, November). Enhancing the engineering curriculum through project-based learning. In Proceedings of the 32nd ASEE/IEEE frontier in education conference. Boston, MA: IEEE Press. Retrieved from http://fie.engrng. pitt.edu/fie2002/papers/1047.pdf

Lejk, M., \& Wyvill, M. (2001). The effect of the inclusion of self-assessment with peer assessment of contributions to a group project: A quantitative study of secret and agreed assessments. Assessment \& Evaluation in Higher Education, 26, 551-561.

Linse, A. R., \& Denton, D. D. (2002, November). Gather student feedback in an international research and design course. In Proceedings of the 32nd ASEE/IEEE Frontier in Education Conference. Boston, MA: IEEE Press.

Pooler, E. (2012, November). Implementing assessment for learning in English language programs. Unpublished paper presented at NEAS Sixteenth Annual ELT management conference. NEAS, Sydney, Australia. Retrieved from www.neas.org.au/ conference/presentations/conf12Pooler.pdf

Segers, M., \& Dochy, F. (2001). New assessment forms in problem-based learning: The value-added of the students' perspective. Studies in Higher Education, 26(3), 327-343.

Stiggins, R., Arter, J., Chappuis, J., \& Chappuis, S. (2004). Classroom assessment for student learning: Doing it right - Using it well. Portland, OR: Assessment Training Institute, Inc. 


\section{ELENA GALICHKINA}

\section{Appendix A}

Self-reflective Weekly Journal

Name: Week number: Dates:

Rating and scores

Comments, etc.

\section{Group Participation}

1. Have I attended group meetings regularly?

2. Have I participated in group discussions? Please specify what you have been discussing.

Self Rating - Group Participation

Select one scale rating.

$\begin{array}{lcccc}1 & 2 & 3 & 4 & 5 \\ \text { Failed } & \begin{array}{c}\text { Needs } \\ \text { improvement }\end{array} & \text { Fair } & \text { Good } & \text { Excellent } \\ \text { Rating: } & & & \end{array}$

Responsibility and Time Management

1. Have I done my share of work? Please specify your responsibilities during this week.

2. Have I kept the time limits for each task?

3. Have I succeeded with my responsibilities?

Self Rating - Responsibility and Time Management

Select one scale rating.

$\begin{array}{lcccc}1 & 2 & 3 & 4 & 5 \\ \text { Failed } & \begin{array}{c}\text { Needs } \\ \text { improvement }\end{array} & \text { Fair } & \text { Good } & \text { Excellent }\end{array}$

Rating: ___ (

\section{Contribution}

1. Have I contributed to the common work during this week? In what way? 2. Have I made any key decisions this week? Which ones?

Self Rating - Contribution

Select one scale rating.

$\begin{array}{ccccc}1 & 2 & 3 & 4 & 5 \\ \text { Failed } & \begin{array}{c}\text { Needs } \\ \text { improvement }\end{array} & \text { Fair } & \text { Good } & \text { Excellent }\end{array}$

Rating: ___ (_

Creativity / Originality

1. Have I originated new ideas? Which ones?

2. Have I initiated team decisions? Which ones?

Self Rating - Creativity / Originality

Select one scale rating.

$\begin{array}{lcccc}1 & 2 & 3 & 4 & 5 \\ \text { Failed } & \begin{array}{c}\text { Needs } \\ \text { improvement }\end{array} & \text { Fair } & \text { Good } & \text { Excellent }\end{array}$

Rating:

\section{Communication Skills}

1. Have I been a good listener? 2. Have I been a capable presenter?

3. Have I been proficient at diagramming and documenting work?

4. Was my language proficiency (grammar and vocabulary) good enough to contribute fully to the project?

Self Rating - Communication Skills

Select one scale rating.

$\begin{array}{lcccc}1 & 2 & 3 & 4 & 5 \\ \text { Failed } & \begin{array}{c}\text { Needs } \\ \text { improvement }\end{array} & \text { Fair } & \text { Good } & \text { Excellent } \\ \text { Rating: } & & & \end{array}$




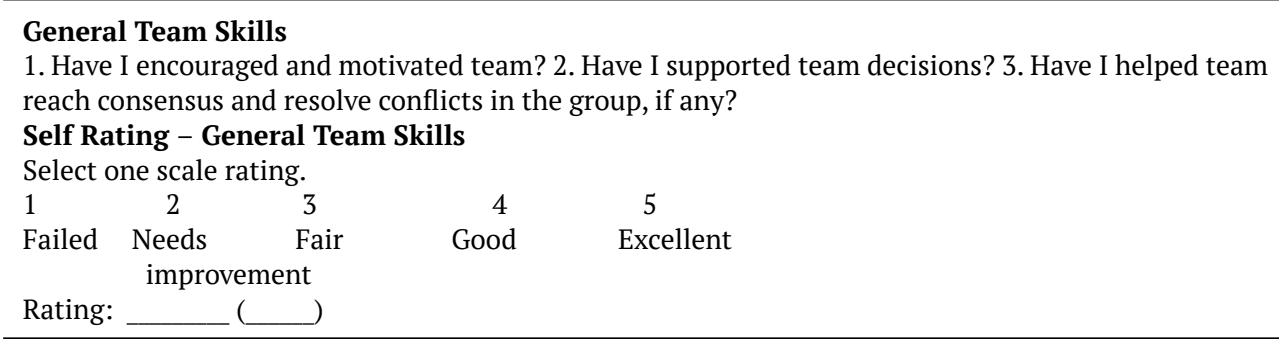

(adapted from Goldfinch, 1994; Lejk and Wyvill, 2001)

\section{Technical Skills}

1. Was I able to create and develop materials on my own initiative?

2. Have I provided technical solutions to problems? Please specify yourself.

Self Rating - Technical Skills

Select one scale rating.

$\begin{array}{lcccc}1 & 2 & 3 & 4 & 5 \\ \text { Failed } & \begin{array}{c}\text { Needs } \\ \text { improvement }\end{array} & \text { Fair } & \text { Good } & \text { Excellent }\end{array}$

Rating:

Scoring

For each category, award yourself a score using this scale.

Excellent $=5$ Good $=4$ Fair $=3$ Needs improvement $=2$ Failed $=1$ 


\section{Appendix B}

\section{Descriptive rubric for grading oral presentation (Individual mark)}

\begin{tabular}{|c|c|c|c|}
\hline & Fair & Good & Excellent \\
\hline Content & $\begin{array}{l}\text { The content is overly } \\
\text { general. Listeners are } \\
\text { unlikely to learn anything } \\
\text { or may be misled. }\end{array}$ & $\begin{array}{l}\text { The content is generally accurate, } \\
\text { but incomplete. } \\
\text { The speakers reached almost all } \\
\text { objectives (presented the results of } \\
\text { the project, provided information } \\
\text { on its goals, target audience, } \\
\text { milestones, presented } \\
\text { survey results, etc). Listeners learn } \\
\text { some isolated facts, but they are } \\
\text { unlikely to gain new insights about } \\
\text { the topic. }\end{array}$ & $\begin{array}{l}\text { The content is accurate and } \\
\text { complete. Speakers reached } \\
\text { objectives (presented the } \\
\text { results of the project, provides } \\
\text { information on its goals, target } \\
\text { audience, milestones, presented } \\
\text { survey results, etc). Listeners gain } \\
\text { new insights about the topic. }\end{array}$ \\
\hline $\begin{array}{l}\text { Fluency and } \\
\text { coherence of speech }\end{array}$ & $\begin{array}{l}\text { The speech is difficult } \\
\text { to understand. It lacks } \\
\text { fluency and cohesion. }\end{array}$ & $\begin{array}{l}\text { The speech is clear and audible } \\
\text { most of the time, but it lacks a bit } \\
\text { of fluency and cohesion. }\end{array}$ & $\begin{array}{l}\text { The speech is clear, fluent, and } \\
\text { coherent and has an appropriate } \\
\text { pace. }\end{array}$ \\
\hline $\begin{array}{l}\text { Awareness of } \\
\text { audience }\end{array}$ & $\begin{array}{l}\text { Shows little awareness of } \\
\text { the audience, doesn't look } \\
\text { at audience, reads notes } \\
\text { or slides }\end{array}$ & $\begin{array}{l}\text { Shows some awareness of audience, } \\
\text { makes infrequent eye contact: } \\
\text { reads notes or slides most of the } \\
\text { time }\end{array}$ & $\begin{array}{l}\text { Shows personal engagement with } \\
\text { audience. Keeps eye contact with } \\
\text { audience most all the time. Avoids } \\
\text { reading from notes. }\end{array}$ \\
\hline Language & $\begin{array}{l}\text { Language proficiency is } \\
\text { below average. Weak use of } \\
\text { vocabulary and no complex } \\
\text { grammar constructions } \\
\text { can be found. }\end{array}$ & $\begin{array}{l}\text { Language proficiency is } \\
\text { intermediate. Average use of } \\
\text { vocabulary and a few complex } \\
\text { grammar constructions. }\end{array}$ & $\begin{array}{l}\text { Language proficiency is above } \\
\text { average. Wide use of vocabulary } \\
\text { and complex grammar } \\
\text { constructions. }\end{array}$ \\
\hline $\begin{array}{l}\text { Response to } \\
\text { questions }\end{array}$ & $\begin{array}{l}\text { Answers are limited with } \\
\text { little or no elaboration. } \\
\text { Shows little knowledge of } \\
\text { area. Unable to respond to } \\
\text { most questions. }\end{array}$ & $\begin{array}{l}\text { Answers are relevant and contain } \\
\text { some elaborated ideas. Shows good } \\
\text { understanding with few mistakes. } \\
\text { Generally able to answer questions } \\
\text { adequately. Short answers. }\end{array}$ & $\begin{array}{l}\text { Answers are relevant, well } \\
\text { thought out and elaborated } \\
\text { on. Demonstrates a high level } \\
\text { of understanding and where } \\
\text { appropriate expands on the } \\
\text { answer. }\end{array}$ \\
\hline $\begin{array}{l}\text { Stayed within time } \\
\text { limit }\end{array}$ & $\begin{array}{l}\text { Didn't stay within time } \\
\text { limit. }\end{array}$ & Mostly stayed within time limit. & Stayed within time limit \\
\hline
\end{tabular}

